\title{
AN OPEN-ACCESS PLATFORM FOR CAMERA-TRAPPING DATA
}

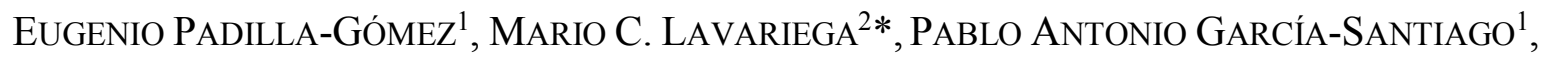 \\ JosÉ SANTIAGO-VELASCO ${ }^{1}$, AND RAÚl OSWALDO MÉNDEZ-MÉNDEZ ${ }^{1}$ \\ ${ }^{1}$ Dirección Sierra Juárez-Mixteca, Comisión Nacional de Áreas Naturales Protegidas, Av. \\ Independencia 709, Centro, Oaxaca de Juárez, 68100, Mexico. ${ }^{2}$ Centro Interdisciplinario \\ de Investigación para el Desarrollo Integral Regional, Unidad Oaxaca, Instituto \\ Politécnico Nacional, Hornos 1003, Santa Cruz Xoxocotlán, Oaxaca, 71230, Mexico. \\ *corresponding author: mariolavnol@yahoo.com.mx
}

\begin{abstract}
In southern Mexico, local communities have been playing important roles in the design and collection of wildlife data through camera-trapping in community-based monitoring of biodiversity projects. However, the methods used to store the data have limited their use in matters of decisionmaking and research. Thus, we present the Platform for Community-based Monitoring of Biodiversity (PCMB), a repository, which allows storage, visualization, and downloading of photographs captured by community-based monitoring of biodiversity projects in protected areas of southern Mexico. The platform was developed using agile software development with extensive interaction between computer scientists and biologists. System development included gathering data, design, built, database and attributes creation, and quality control. The PCMB currently contains 28,180 images of 6478 animals (69.4\% mammals and $30.3 \%$ birds). Of the 32 species of mammals recorded in 18 PA since 2012, approximately a quarter of all photographs were of white-tailed deer (Odocoileus virginianus). Platforms permitting access to camera-trapping data are a valuable step in opening access to data of biodiversity; the PCMB is a practical new tool for wildlife management and research with data generated through local participation. Thus, this work encourages research on the data generated through the communitybased monitoring of biodiversity projects in protected areas, to provide an important information infrastructure for effective management and conservation of wildlife.
\end{abstract}

Key words: agile software development, community-based monitoring, community conservation areas, protected areas, Oaxaca.

Community-based monitoring of biodiversity $(\mathrm{CBM})$ requires participation of local people in study design and data collection (Meffe et al. 2002, Danielsen et al. 2007, Conrad and Hilchey 2011). This local intervention increases probability of success of conservation projects because it creates a sense of ownership among participants (Danielsen et al. 2007, Conrad and Hilchey 2011, Dickinson et al. 2012). CBM yields other benefits, such as creation of local employment, increased human capital, and increased tolerance of humanwildlife conflicts (Treves et al. 2009, Burton 2012). CBM is particularly necessary in areas with high biological and cultural diversity, as well as in areas where land tenure is communal, as in state of Oaxaca in southern Mexico.

Oaxaca holds some of the richest biodiversity in Mexico (Flores-Villela and García-Vázquez 2014, Navarro-Sigüenza et al. 2014, Parra-Olea et al. 2014, Sánchez-Cordero et al. 2014, Villaseñor and Ortiz 2014). It also has impressive human ethnic diversity: 16 of the 58 native groups of Mexico, and 158 of the 291 known languages in the country (De Ávila 2008). Almost $70 \%$ of its territory is under communal land tenure, and community members carry out decisions about management of natural resources (Bray et al. 2008, Martin et al. 2011). Communities of Oaxaca have been pioneers in community conservation processes (De la Maza 2010); currently, at least 880 community conservation areas and 12 governmental protected areas exist in the state, together protecting $12 \%$ of the state's land area (BrionesSalas et al. 2016).

To involve landowners in gathering data of wildlife populations, the Mexican government has implemented the CBM projects (CONANP 2016). The purpose of these projects is to provide equipment and training to local people on use of camera-traps and global positioning systems; 
count and photograph mammal signs; census birds; and update databases (CONANP 2016). In the last three years, CBM projects in protected areas of Oaxaca have generated $\sim 150,000$ photographs and videos. However, the resulting data are being stored in ways that restrict access to the information, thereby limiting their use in decision-making and research. Since analyses of wildlife data are essential to conservation and management efforts (Meffee et al. 2002), open access to biodiversity data becomes crucial (Molloy 2011, Thessen and Patterson 2011, Hanssen et al. 2014).

Because biodiversity processes are dynamic - and conservation and management efforts must be designed to incorporate this characteristic - it is crucial to implement tools that allow prompt distribution of information regarding occurrences of species, their abundance, their trends, and their ecosystem services (Thessen and Patterson 2011, Nesshöver et al. 2016). As such, biodiversity data repositories have proven crucial in supporting management efforts, adding to scientific knowledge, and increasing citizen appreciation of biodiversity (Conrad and Hilchey 2011, Thessen and Patterson 2011).

Therefore, with the goals of processing large amounts of data, assembling geographic information with photographic records, and providing educational materials in accessible formats, a platform for serving data resulting from biodiversity monitoring was created. The aim of this work is to present the development of the Platform for Community-based Monitoring of Biodiversity $\left(\mathrm{PCBM}^{1}\right)$.

\section{MATERIALS AND METHODS Study Site}

Community-based monitoring of biodiversity projects had been implemented in 18 protected areas in southern Mexico, distributed in various sectors of the region: the Western Mountains and Valleys (Mixteca region), Sierra Madre de Oaxaca, Central Valleys of Oaxaca, Central Mountains and Valleys, and Balsas Depression physiographic sub-provinces (Figure 1). The Western Mountains and Valleys are characterized by temperate climate, holding pine forest and pine-oak forest, and at low elevations tropical deciduous forests. The Sierra Madre de Oaxaca, in northern Oaxaca, holds pine-oak forest, oak forest, and montane cloud forest. Tropical perennial forest is found in the foothills. Lowlands and knolls dominate the Central Valleys of Oaxaca, where landscapes have been modified for agriculture, pastureland, and settlements, in a tropical climate setting (OrtizPérez 2004, INEGI 2013).

\section{Community-based Monitoring of Biodiversity}

Since 2011, the Sierra Juárez-Mixteca Office of the Mexican National Commission of Natural Protected Areas began implementing programs aimed at raising awareness of the significance of conservation in protected areas located in Oaxaca. In a series of meetings, we presented program objectives for wildlife monitoring to the authorities of communities and community assemblies in protected areas. To involve local people in monitoring, incentives provided included equipment, training, temporary employment, and field assistance, with regular reports.

Members of monitoring committees were selected by the community assemblies, with basis on experience in conservation projects and knowledge of the territory. In workshops, monitoring committees were trained in use of camera traps, geographic positioning systems (GPS), cameras, and databases. Numbers of camera traps in communities were a function of the annual budget of the Sierra Juárez-Mixteca Office and ranged 4-10 devices. During surveys, monitoring committees followed standardized protocols for camera-trap data collection (Chávez et al. 2013, Padilla-Gómez et al. 2015).

Training protocols included details of distances between camera traps (1-3 km), placement of camera traps at sites (i.e., distance between targets and camera traps, height above the ground, and orientation with respect to sunlight), and several dry-run tests. An important element was recording geographic coordinates and elevation with a GPS of each camera trap site. Experienced team members accompanied monitoring committees during initial field surveys and at intervals thereafter. Camera traps 


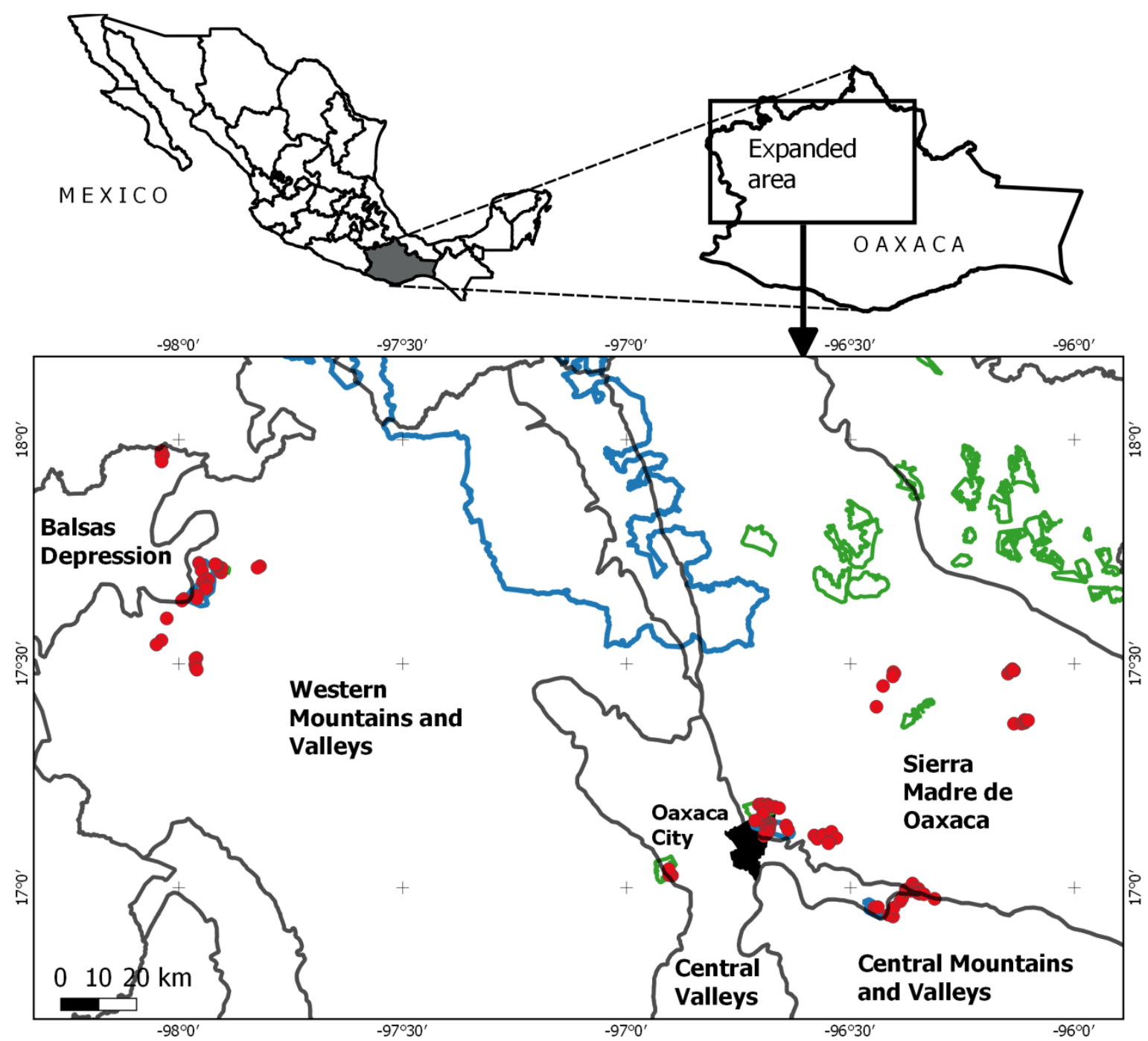

Figure 1. Map showing the study area. Red dots show locations of camera traps; gray polygons show administrative boundaries of subprovinces; blue polygons show Mexican government protected areas; and green polygons show areas voluntarily destined for conservation.

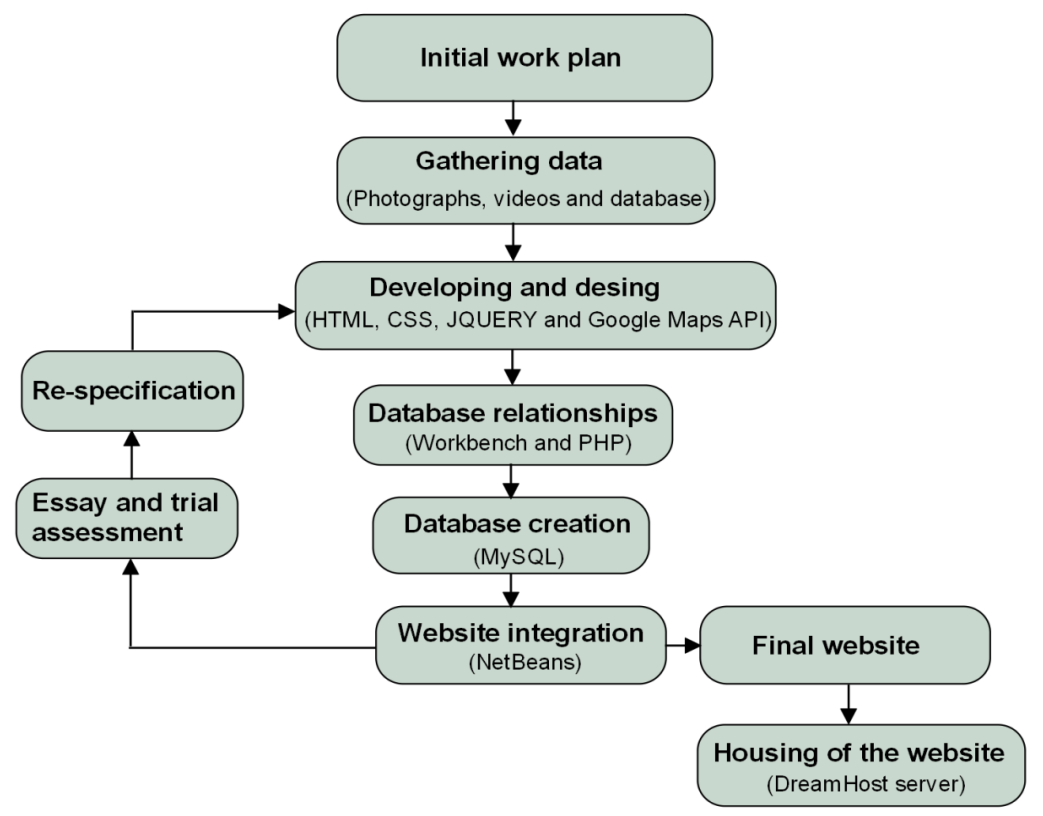

Figure 2. Workflow in development of the Platform for Community-based Monitoring of Biodiversity. 
were checked every $\sim 15$ days to download the images and change batteries. Camera traps remained in the field for $1-6$ months whenever feasible.

\section{Platform Development}

The PCMB was developed using an agile software development approach. The process consisted of an initial work plan and several proofing cycles that included testing, assessment, and improvement until the platform was functioning according to desired objectives (Pressman 2006). These iterations were carried out via multiple meetings between computer scientists and biologists, which improved the workflow greatly (Figure 2). System development was conducted in three stages: (1) gathering data, in which photographs, videos, and data acquired were compiled; (2) development and design of the platform, in which the maps module was created to feature an interactive map showing the locations of the camera-trap stations via GoogleEarth ${ }^{\mathrm{TM}}$; and (3) designing database relationships using Workbench software ${ }^{2}$ (Pressman 2006), and developing schemes to show relationships between data and attributes in the databases. The database was created in MySQL. Once diagrams were built, a database with all information on the biodiversity of each protected area was created.

All interfaces were designed using HyperText Markup Language (HTML) and Cascading Style Sheets (CSS) to create the appearance of a web page. The website was developed using the Pre Hypertext Processor (PHP) programming language to link the site to the databases, organize the data, and return the content as HTML to the browser. To simplify interactions between HTML documents and to make pages more dynamic, the JQUERY library of the JavaScript programming language was used, which includes plug-ins like JQUERY.VALIDATE, JQUERY.UI, JQUERY.AUTOSIZE and MODERNIZR. Finally, NetBeans was used to integrate the website; for geographic information, the Google Earth and Google Maps APIs were used. Once completed, the platform was housed in a

\footnotetext{
${ }^{2}$ https://www.mysql.com/products/workbench/

3 http://rs.tdwg.org/dwc/

4 http://www.naturalista.mx/
}

DreamHost server, which provided flexibility to the site in terms of storing capacity and speed connection.

The platform allows access to two types of users: managers and users. The manager has control over stored information through the attribute options. This interface includes options to convert Excel databases to tables in Darwin Core $^{3}$ format, and to label photographs also in Darwin Core format (Wieczorek et al. 2012).

Meanwhile, the user or visitor can access an interactive Google Earth map showing locations of camera trap stations. The visitor can perform a search on species or biodiversity measures, using filters such year, month, activity patterns, protected area, and vegetation type, and download a data table in Excel. The platform also generates Quick Response (QR) codes for each camera trap station, so a $\mathrm{QR}$ reader can view species recorded in each of them. For each photograph, the platform can generate a standardized data card with appropriate metadata (Botello et al. 2007, Thessen and Patterson 2011, Wihtlock 2011; Figure 3). It can also generate a fact sheet for display or download as a PDF with information on each species recorded in a protected area.

\section{Interoperability}

In the PCMB, we added the capability to export data in Darwin Core format (Tegelberg et al. 2012). It also can migrate data to Naturalista ${ }^{4}$, the main citizen-science platform in Mexico (Koleff et al. 2014), and the Global Biodiversity Information Facility (GBIF) platform ${ }^{5}$ (Graham et al. 2004). To this end, a script was created in the PCMB that generates a file of metadata resources, a metafile describing the content and relationships of text files in the Darwin Core file, and a text data file. The information is then sent to the National Biodiversity Information System (SNIB), which is housed by the National Commission for the Knowledge and Use of Biodiversity $\left(\mathrm{CONABIO}^{6}\right)$ and linked to GBIF. Although in the current version of the PCMB, the Audubon Core metadata schema (Morris et al. 2013) was not considered, it could be integrated in the future.

\footnotetext{
${ }^{5} \mathrm{http://www.gbif.org/}$

${ }^{6}$ https://www.gob.mx/conabio
} 


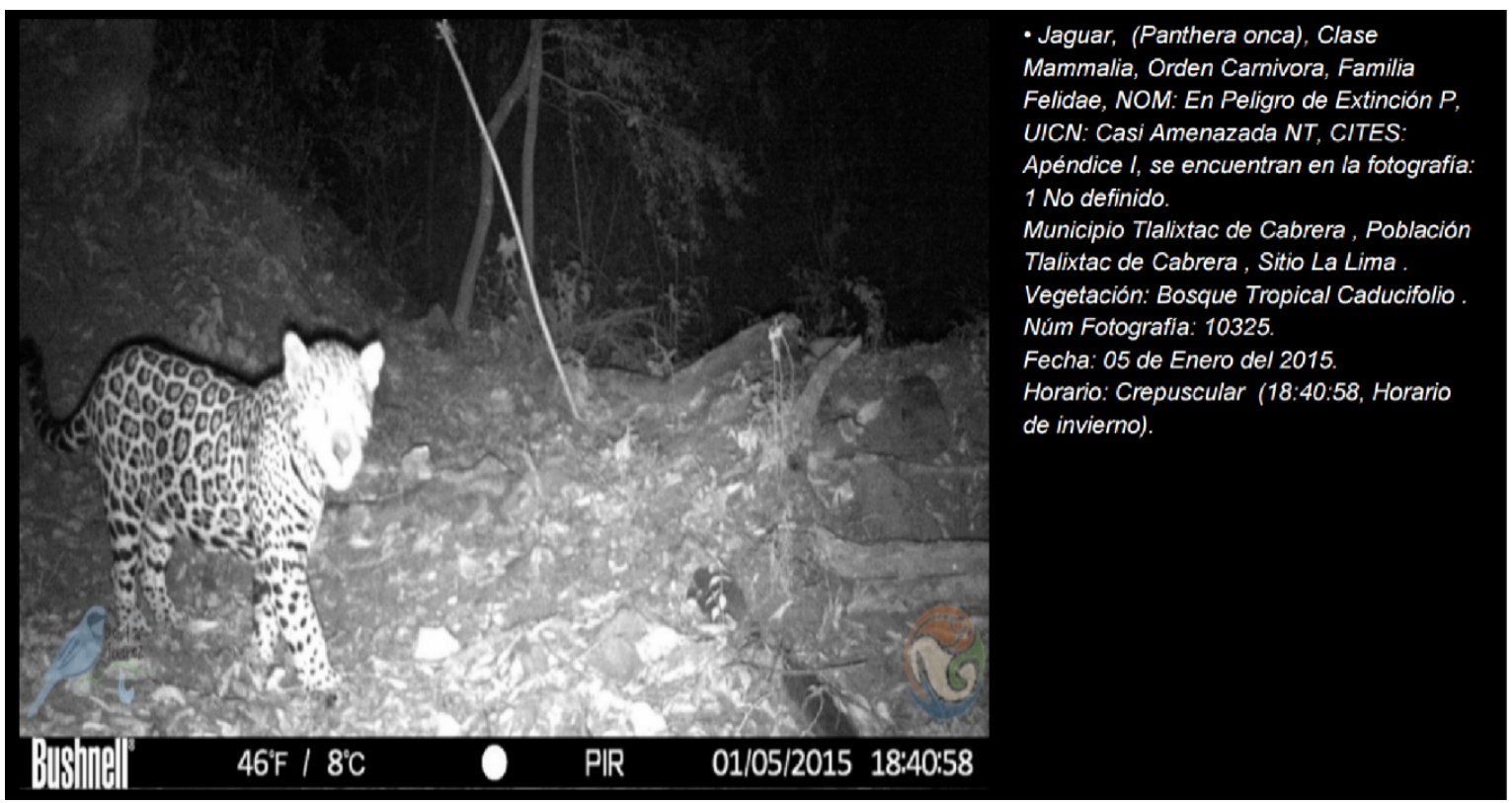

Figure 3. Example of a standardized data card generated by the Platform for Community-based Monitoring of Biodiversity, corresponding to a photographic record of a jaguar (Panthera onca).
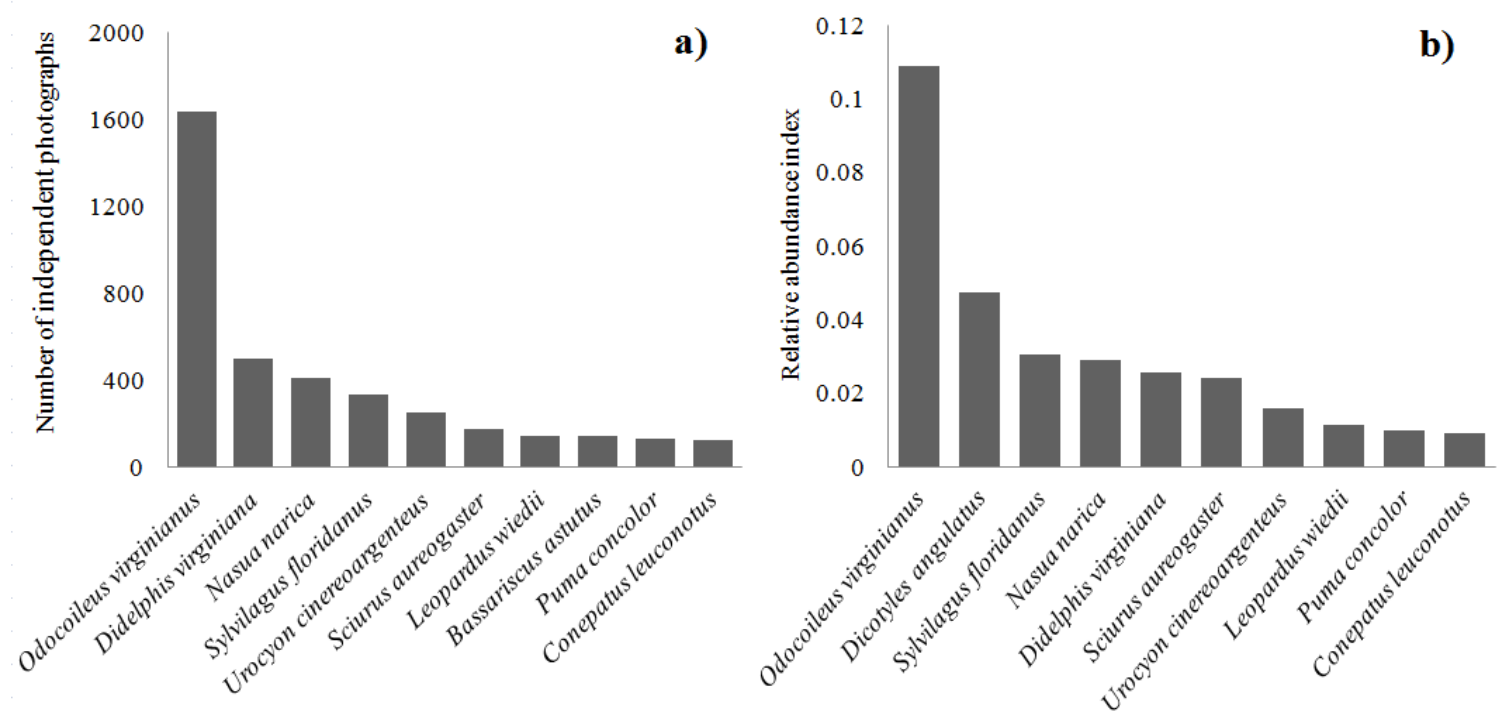

Figure 4. Mammal species with highest numbers of independent photographic records (a) and the highest relative abundance index (b) deposited in the Platform for Community-based Monitoring of Biodiversity. 


\section{Data Workflow}

During surveys, monitoring committees downloaded images, naming them according to the camera trap site. Subsequently, we visited communities within the program to gather images and associated data. Data were centralized and stored at the Sierra JuárezMixteca headquarters.

Before uploading photographs to the platform, a team of experts on mammals or birds identified the animals in each photograph. These specialists acted as a quality control (Thessen and Patterson 2011). Photographs were considered as independent and uploaded to the platform when they met the following criteria (Monroy-Vilchis et al. 2011): (1) pertaining to different individuals, and (2) same individual or species taken at intervals of $>24 \mathrm{hr}$.

\section{Data Analysis}

Biodiversity measures implemented in PCMB included species richness, frequency index, relative-abundance index, and diversity index. We also included number of species in categories of threat and protection according to the Mexican Norma Oficial 059 (SEMARNAT 2010), number of species in the Red List (IUCN $2016^{7}$ ), number of species listed in the appendices of the Convention on International Trade in Endangered Species of Wild Fauna and Flora $\left(\mathrm{CITES}^{8}\right)$, and number of endemic species (Briones-Salas et al. 2015).

\section{RESULTS}

The PCMB was finished and launched in June 2015. To date, the data comprise 6478 independent photographs of 28,180 records obtained since 2012. Photographs correspond mainly to mammals (4497 photographs; 69.4\%) and birds (1962 photographs; 30.3\%). The rest were images of reptiles (16 photographs; $0.2 \%$ ). In all, 4000 independent photographs and associated metadata have been shared with CONABIO, the Mexican node of GBIF.

\section{Mammal Species Diversity}

Over the course of the project, 32 species of medium and large-sized mammals were recorded in the protected areas. The average number of species documented in protected areas was 12.2 (range 4-21). Eight species, including coati (Nasua narica), white-tailed deer (Odocoileus virginianus), and gray fox (Urocyon cinereoargenteus) were found regularly in protected areas, being recorded in $\geq 10$ areas. In contrast, the striped hog-nosed skunk (Conepatus semistriatus), ocelot (Leopardus pardalis), long-tailed weasel (Mustela frenata), and red brocket deer (Mazama temama) were recorded only in one PA each one.

One quarter $(25.2 \%)$ of all independent photographs were of white-tailed deer. The species with the second largest number of independent photographs was opossum (Didelphis virginiana; 7.7\%), followed by coati (6.3\%; Figure $4 a)$. The relative abundance index was highest for white-tailed deer, followed by collared peccary (Pecari tajacu) and Eastern cottontail (Sylvilagus floridanus; Figure 3b).

\section{Conservation Status}

We found 7 mammal species listed in the Mexican Norma Oficial: Baird's tapir (Tapirella bairdii), jaguar, ocelot, margay (Leopardus wiedii), and tayra (Eira barbara) were listed as endangered; hog-nosed skunk is listed as subject to special protection; and yagouaroundi (Herpailurus yagouaroundi) is threatened (SEMARNAT 2010). Worldwide, the Mexican agouti (Dasyprocta mexicana) is considered as critically endangered; Baird's tapir is considered as endangered; and jaguar and margay are near threatened (IUCN 2016). Seven species were listed in the appendices of the CITES: Baird's tapir, jaguar ocelot, margay, and yagouaroundi are in Appendix I, and bobcat and puma (Puma concolor) are in Appendix II (CITES 2015).

\section{DISCUSSION}

PCMB is an innovative platform of biodiversity data developed to centralize, standardize, and serve open-access biodiversity data and analyses from community-based monitoring $(\mathrm{CBM})$ projects using camera traps in protected areas of southern Mexico. PCMB is proposed to advance wildlife management and conservation efforts in protected areas. In addition, the platform fosters collaboration and 
exchange of information among specialists, scholars, researchers, and the general public through consultation and decision making.

Four additional platforms now provide camera-trap data, including Wildlife Insights ${ }^{9}$, eMammal $^{10}$, DeskTEAM ${ }^{11}$, and the WII camera trap data web portal ${ }^{12}$. These platforms and PCMB share the objectives of data mobilization from camera-trapping projects (Fegraus et al. 2011, Hanssen et al. 2014). PCMB is comparable to DeskTEAM and the WII portal. DeskTEAM is a partnership among Conservation International, Missouri Botanical Garden, Wildlife Conservation Society, and Smithsonian Institution (Fegraus et al. 2011). The WII portal resulted from a collaboration between Indian and Norwegian researchers (Hanssen et al. 2014).

Emphasis on local participation in DeskTEAM and PCMB is an important difference from the WII portal (Fegraus et al. 2011). For example, the WII portal includes only a very few CBM studies (wild mammal biodiversity in the Pune District), with most data coming from specialized researchers. DeskTEAM, eMammal, and PCMB include training in use of camera-traps (in-person or online): eMammal users pay subscription fees, whereas DeskTEAM and PCMB are free of cost. eMammal presently serves data from 64 projects, and DeskTEAM from 16 projects, both worldwide. PCMB manages data from projects in 18 sites, all in southern Mexico, although it can manage data from anywhere. A next step of these different camera-trap data repositories should be to integrate or share data between platforms, as proposed by Forrester et al. (2016).

Thessen and Patterson (2011) noted that a problem with repositories developed through projects is lack of long-term funding. eMammal is a non-governmental initiative, supported by subscription fees. Wildlife Insights and DeskTEAM are supported by non-governmental and private agencies. The WII portal is supported by the Norwegian and Indian governments, while PCMB is supported by the Mexican government.

Despite the differences, all of these platforms fit one of the core goals of the Intergovernmental Platform on Biodiversity and

\footnotetext{
${ }^{9} \mathrm{https}: / /$ www.wildlifeinsights.org

${ }^{10}$ http://emammal.si.edu/
}

Ecosystem Services (IPBES) by "filling knowledge gaps; build local capacities; and assessing the state of the planet's biodiversity" (Kok et al. 2016, Schmeller and Bridgewater 2016). These platforms provide access to unique data resources, protect the integrity of the data, and incorporate normalization, standardization, automation, quality control, and analysis of the data (Thessen and Patterson 2011). Through these platforms, decision makers and nonspecialists can learn about the presence of medium and large-sized mammals around the world (Hanssen et al. 2014, Fegraus and MacCarthy 2016).

Projects implemented in southern Mexico have sought to integrate local communities since their initiation (CONANP 2016). We noted that, at the beginning, villagers regarded the project as just another task. However, after retrieving the first images captured with the camera-traps, persons involved in the monitoring committees were able to see the different species of mammals and birds that inhabit their forests. In many cases, local residents did not know that particular species inhabited their lands because of nocturnal or shy habits. Photographs of jaguars, puma with cubs, margay, jaguarondi, and lynx (Lynx rufus) were distributed among the local population through cell phones.

Most communities where biological monitoring has been implemented have received some level of economic support, which, although insufficient, allows them to carry out monitoring activities. Interestingly, we noted that some communities have continued to monitor even without any financial support. PCMB facilitates evaluation of efforts by communities to protect wild species. The long-term continuity of biodiversity monitoring nonetheless will depend on the funding received. Thus, funding for these programs should be considered an investment that will eventually yield earnings in research, evidence-based management, and wildlife conservation (Molloy 2013, Piwowar et al. 2011, Fegraus and MacCarthy 2016).

As a whole, this project recorded 32 medium and large-sized mammal species, which documents in these protected areas almost $60 \%$

\footnotetext{
${ }^{11} \mathrm{http}: / /$ www.teamnetwork.org/

12 http://www.wii.gov.in/.
} 
of the medium and large mammals of Oaxaca (Briones-Salas et al. 2015). Through this paper, we seek to encourage research from communitybased monitoring of biodiversity projects in protected areas to improve the tools and knowledge available for effective wildlife management and conservation. PCMB has already made important contributions to the general knowledge and information regarding the conservation of several threatened and endangered mammals, and offers additional opportunities for projects related to biogeography and ecosystem services. PCMB provides open-access to camera-traps records gathered by local committees contributing to the dissemination of knowledge to inform biodiversity conservation efforts.

\section{ACKNOWLEDGMENTS}

We thank the monitoring committees of Ejido Donají, Tlalixtac Cabrera, San Pablo Etla, San Andrés Ixtlahuaca, Santo Domingo Tonalá, Agencia Santa Catarina, San Marcos Arteaga, Santa Maria Tindú, San Francisco Yosocuta, Santa Catarina Estancia, Santiago Asunción, Yagul, Villa Díaz Ordaz, Ejido Union Zapata, Villa de Mitla, Santa Catarina Yetzelalag, and San Juan Yetzecobi. Anne Thessen and Joe Figel reviewed drafts of this manuscript; M. García and A. Polo improved the English. Anonymous reviewers and editors for their input in helping to improve the manuscript. Pavel Palacios and the Sierra Norte Mixteca Office provided important support. This work was supported by Proyecto Mixteca, National Commission of Natural Protected Areas, Global Environmental Fund, U.N. Environment Programme, and World Wildlife Fund.

\section{LITERATURE CITED}

Botello, F., G. Monroy, P. lloldi-Rangel, I. TrujilloBolio, and V. Sánchez-Cordero. 2007. Sistematización de imágenes obtenidas por fototrampeo: una propuesta de ficha. Revista Mexicana de Biodiversidad 78:207-210.

Bray, D.B., L. Merino, P. Negreros-Castillo, G. Segura-Warnholtz, J.M. Torres-Rojo, and H.F.M. Vester. 2003. Mexico's community-managed forests as a global model for sustainable landscapes. Conservation Biology 17:672-677.

Briones-Salas, M., M. Cortés-Marcial, and M.C. Lavariega. 2015. Diversidad y distribución geográfica de los mamíferos terrestres del estado de Oaxaca, México. Revista Mexicana de Biodiversidad 86:685-710.

Briones-Salas, M., M.C. Lavariega, M. CortésMarcial, A.G. Monroy-Gamboa, and C.A. MasesGarcía. 2016. Iniciativas de Conservación para los Mamíferos de Oaxaca, México. In: M. BrionesSalas, Y. Hortelano-Moncada, G. Magaña-Cota, G. Sánchez-Rojas, \& J.E. Sosa-Escalante (eds.), Riqueza y Conservación de los Mamíferos en México a Nivel Estatal, Instituto de Biología, Universidad Nacional Autónoma de México, Mexico City. pp. 329-366.

Burton, A.C. 2012. Critical evaluation of a long-term, locally-based monitoring program in West Africa. Biodiversity Conservation 21:3079-3094.

Chávez, C., A. de la Torre, H. Bárcenas, R.A. Medellín, H. Zarza, and G. Ceballos. 2013. Manual de Fototrampeo para Estudio de la Fauna Silvestre. El Jaguar en México Como Estudio de Caso. Alianza WWF-Telcel, Universidad Nacional Autónoma de México, Mexico City.

CITES, Convention on International Trade in Endangered Species of Wild Fauna and Flora. 2015. Appendices I, II, and III. Convention on International Trade in Endangered Species of Wild Fauna and Flora, Geneva.

CONANP, Comisión Nacional de Áreas Naturales Protegidas. 2016. Programa de Conservación para el Desarrollo Sostenible. Comisión Nacional de Áreas Naturales Protegidas, Mexico City.

Conrad, C.C., and K.G. Hilchey. 2011. A review of citizen science and community-based environmental monitoring: issues and opportunities. Environmental Monitoring and Assessment 176:273-291.

Danielsen, F., M.M. Mendoza, A. Tagtag, P.A. Alviola, D.S. Balete, A.E. Jensen, M. Enghoff, and M.K. Poulsen. 2007. Increasing conservation management action by involving local people in natural resource monitoring. Ambio 36:566-570.

De Ávila, A. 2008. La Diversidad Lingüística y el Conocimiento Etnobiológico. In: CONABIO (ed.), Capital natural de México, vol. I: Conocimiento Actual de la Biodiversidad. Comisión Nacional para el Conocimiento y Uso de la Biodiverssidad, Mexico City. pp. 497-556.

De la Maza, J. 2010. Áreas Naturales Certificadas. In: J. Carabias, J. Sarukhán, J. de la Maza, \& C. Galindo (eds.), Patrimonio Natural de México Cien Casos de Exito. Comisión Nacional para el Conocimiento y Uso de la Biodiversidad, Mexico City. pp. 18-19.

Dickinson, J.L., J. Shirk, D. Boner, R. Bonney, R.L. Crain, J. Martin, T. Phillips, and K. Purcell. 2012. The current state of citizen science as tool for 
ecological research and public engagement. Frontiers in Ecology and the Environment 10:291297.

Fegraus, E., K. Lin, J.A. Ahumada, C. Baru, S. Chancra, and C. Youn. 2011. Data Acquisition and management software for camera trap data: a case study from the TEAM network. Ecological Informatics 6:345-353.

Fegraus, E., and J. MacCarthy. 2016. Camera trap data management and interoperability. In: F. Rovero, \& F. Zimmermann (eds.), Camera Trapping for Wildlife Research. Pelagic Publishing, Exeter, United Kingdom. pp. 33-42.

Flores-Villela, O., and U. García-Vázquez. 2014. Biodiversidad de reptiles en México. Revista Mexicana de Biodiversidad 85:S467-S475.

Graham, C.H., S. Ferrier, F. Huettman, C. Moritz, and A.T. Peterson. 2004. New developments in museum-based informatics and applications in biodiversity analysis. Trends in Ecology and Evolution 19:497-503.

Hanssen, F., V.B. Mathur, V. Athreya, V. Barve, R. Bhardwaj, L. Boumans, M. Cadman, V. Chavan, M. Ghosh, A. Lindgaard, Ø. Lofthus, B. Mehlum, B. Pandav, G.A. Punjabi, A. González, G. Talukdar, N. Valland, and R. Vang, 2014. Capacity Building for Intergovernmental Platform for Biodiversity and Ecosystem Services (IPBES). Final report 2014: Indo-Norwegian Pilot Project on Capacity Building in Biodiversity Informatics for Enhanced Decision Making, Improved Nature Conservation and Sustainable Development. NINA Report 1079, Norway.

INEGI. 2013. Vectorial Map of Land Use and Vegetation, Series V, scale 1:250,000. Instituto Nacional de Estadística, Geografía e Informática, Mexico.

IUCN. 2016. Red List of Threatened Species. International Union for Conservancy of Nature and Natural Resources, Switzerland.

Jost, L. 2006. Partitioning diversity into independent alpha and beta components. Ecology 88:24272439.

Kok, M.T.J., K. Kok, G.D. Peterson, R. Hill, J. Agard, and S.R. Carpenter. 2016. Biodiversity and ecosystem services require IPBES to take novel approach to scenarios. Sustainability Science $12: 1-5$.

Koleff, P., T. Urquiza-Haas, and J. Sarukhán. 2014. Scientific evaluation of biological diversity: process, needs, challenges and perspectives. Investigaciones Ambientales 6:61-75.

Martin, G.J., C.I. Camacho, C.A. Del Campo, S. Anta, F. Chapela, and M.A. González. 2011. Indigenous and community conserved areas in Oaxaca,
Mexico. Management of Environmental Quality 22:250-266.

Meffe, G., L. Nielsen, R.L. Knight, and D. Schenborn. 2002. Ecosystem Management: Adaptive, Community-based Conservation. Island Press, Washington.

Molloy, J.C. 2011. The Open Knowledge Foundation: open data means better science. PLoS Biology 9:1-4.

Monroy-Vilchis, O., M.M. Zarco-González, and C. Rodríguez-Soto. 2011. Fototrampeo de mamíferos en la Sierra Nanchititla. Revista de Biología Tropical 59:373-383.

Moreno, C.E., F. Barragán, E. Pineda, and N.P. Pavón. 2011. Reanálisis de la diversidad alfa: alternativas para interpretar y comparar información sobre comunidades ecológicas. Revista Mexicana de Biodiversidad 82:12491261.

Morris, R.A., V. Barve, M. Carausu, V. Chavan, J. Cuadra, C. Freeland, G. Hagedorn, P. Leary, M. Mozzherin, A. Olson, G. Riccardi, I. Teage, and G. Whitbread. 2013. Discovery and publishing of primary biodiversity data associated with multimedia resources: the Audubon Core strategies and approaches. Biodiversity Informatics 8:185-197.

Navarro-Sigüenza, A.G., M.F. Rebón-Gallardo, A. Gordillo-Martínez, A.T. Peterson, H. BerlangaGarcía, and L.A. Sánchez-González. 2014. Biodiversidad de aves en México. Revista Mexicana de Biodiversidad 85:S476-S495.

Nesshöver, C., B. Livoreil, S. Schindler, and M. Vandewall. 2016. Challenges and solutions for networking knowledge holders and better informing decision-making on biodiversity and ecosystem services. Biodiversity Conservation 25:1215-1233.

Ortiz-Pérez, M.A., J.R. Hernández, and J.M. Figueroa. 2004. Reconocimiento fisiográfico y geomorfológico. In: A.J. García Mendoza, M.J. Ordóñez, and M. Briones-Salas (eds.) Biodiversidad de Oaxaca. Instituto de Biología, Universidad Nacional Autónoma de México, Mexico City. pp. 43-54.

Padilla-Gómez E., M.C. Lavariega, and R. FloresDiego. 2015. Protocolo Estandarizado para las ANP que Atiende las Dirección Sierra JuárezMixteca. World Wildlife Fund, Oaxaca, Mexico.

Parra-Olea, G., O. Flores-Villela, and C. MendozaAlmerall. 2014. Biodiversidad de anfibios en México. Revista Mexicana de Biodiversidad 85:S460-S466.

Piwowar, H.A., T.J. Vision, and M.C. Whitlock. 2011. Data archiving is a good investment. Nature 473. 
Pressman, R.S. 2006. Ingeniería del Software un Enfoque Práctico. McGraw Hill, Mexico City.

Sánchez-Cordero, V., F. Botello, J.J. Flores-Martínez, R.A. Gómez-Rodríguez, L. Guevara, G. Gutiérrez-Granados, and A. Rodríguez-Moreno. 2014. Biodiversidad de Chordata (Mammalia) en México. Revista Mexicana de Biodiversidad 85:S496-S504.

Schmeller, D.S., and P. Bridgewater. 2016. The Intergovernmental Platform on Biodiversity and Ecosystem Services (IPBES): progress and next steps. Biodiversity Conservation 25:801-805.

SEMARNAT, Secretaría de Medio Ambiente y Recursos Naturales. 2010. Norma Oficial Mexicana NOM-059-SEMARNAT-2010, Protección Ambiental-especies Nativas de México de Flora y Fauna Silvestres - categorías de Riesgo y Especificaciones para su Inclusión, Exclusión o Cambio-lista de Especies en Riesgo. Diario Oficial de la Federacion 2454:1-77.

Sergio, F., T. Caro, D. Brown, B. Clucas, J. Hunter, J. Ketchum, K. McHugh, and F. Hiraldo. 2008. Top predators as conservation tools: ecological rationale, assumptions, and efficacy. Annual Review of Ecology, Evolution and Systematics 39:1-19.

Tegelberg, R., J. Haapala, T. Mononen, M. Pajari, and H. Saarenmaa. 2012. The development of a digitizing service center for natural history collections. In: V. Blagodev, \& V.S. Smith (eds.), No Specimen Left Behind: Mass Digitization of Natural History Collections. ZooKeys, Bulgaria. pp. 75-86.

Thessen, A.E., and D.J. Patterson. 2011. Data issues in the life sciences. In: V. Blagodev, \& V.S. Smith (eds.), No specimen left behind: mass digitization of natural history collections. ZooKeys, Bulgaria. pp. 15-51.

Treves, A., R.B. Wallace, and S. White. 2009. Participatory planning of interventions to mitigate human-wildlife conflicts. Conservation Biology 23:1523-1739.

Villaseñor, J.L., and E. Ortiz. 2014. Biodiversidad de las plantas con flores (División Magnoliophyta) en México. Revista Mexicana de Biodiversidad 85:S134-S142.

Wieczorek, J., D. Bloom, R. Guralnick, S. Blum, M. Döring, R. Giovanni, T. Robertson, and D. Vieglais. 2012. Darwin Core: an evolving community-developed biodiversity data standard. PLoS ONE 7:e29715.

Whitlock, M.C. 2011. Data archiving in ecology and evolution: best practices. Trends in Ecology and Evolution 26:61-65. 